\title{
STRATEGIC ANALYSIS OF ZALAEGERSZEG PROVING GROUND
}

UDC: 629.331:330.322(439)

Original Scientific Paper

\author{
Károly SZABÓ ${ }^{1}$, László SZABÓ ${ }^{2}$, Ágnes CSANÁDI ${ }^{1}$ \\ ${ }^{1}$ Budapest Business School, Zalaegerszeg Faculty of Business Administration, H-8900 Zalaegerszeg, Gasparich \\ Márk str. 18/a, Hungary, \\ ${ }^{2}$ Budapest Business School, Zalaegerszeg Faculty of Business Administration, H-8900 Zalaegerszeg, Gasparich \\ Márk str. 18/a Hungary, \\ E-mail: szabo.laszlo4@uni-bge.hu
}

Paper received: 23.05.2020.; Paper accepted: 05.06.2020.

The investment of the Zalaegerszeg Proving Ground was finalized by a government decree - nr. 1292/2016. (VI. 13.) - which was a final result of a 2-year-long teamwork on the overall preparation, resource management and other return analysis calculations. The construction began in 2017, after which the first phase was finished in 2018 - as it was previously planned - while the final date for development is scheduled for the end of 2020 . The current paper will outline the future alternatives for the proving ground in the field of the possible operation and return on investment performance from the strategic side. The most important goal of the analysis was to explore the potential outputs of the investment, which gives us a better insight into the economic, social and other effects of the test track.

Keywords: Automotive; Proving ground; Strategy.

\section{INTRODUCTIONS}

In the last twenty years, the automotive industry has become the driving force of the economy in Hungary. This can be also seen in the number of the produced cars, in which the locally manufactured vehicles output was more than 568 thousand in 2017. Therefore, the Hungarian government attributes a great importance to the construction of the Zalaegerszeg Automotive Test Track, which - compared to conventional test tracks - offers great research and testing possibilities of the future vehicle technologies, such as electric and self - driving vehicles, in addition to vehicle dynamics applications focusing on driveability and driving stability. The first phase of the 250-hectare track was finished in 2018 and is expected to be fully completed by 2020 . (Hungarian Government, 2011).

As it is clearly visible in the short conclusion of the implemented development, Zala Zone will be an automotive test track or by its other name proving ground. The proving ground as automotive solution is an existing concept for decades, so it's evident, we can find many good practices worldwide at the topic area. Firstly - as introduction - it is important to clarify the definition of test track.

If we want to define a proving ground's activity in the automotive industry, the following definition can give the clearest description: "An important phase of the automotive $R \& D$ is the testing of components or complete vehicle constructions created on the design table or tested on prototypes under laboratory conditions - on closed, safe tracks providing standardized surfaces that approximate real conditions. Test tracks in the automotive industry are being built for this purpose." (Haas, \& Cselle, 2017).

It's hard to define the actual number of the existing proving grounds in the world as the concept of the common test track used by several companies is a relatively new approach. Car manufacturers have typically developed their own tracks, but these have represented a lower level of infrastructure compared to the test track centers currently being 
formed. In the absence of an accurate estimate, we will list the best-known test tracks:

- Boxberg Proving Ground, Germany, Boxberg (ww.bosch-mobility-solutions.com)

- Papenburg Handling Course, Germany (www.atppbg.de)

- ATC - Aldenhoven RWTH, Germany (www.atc-aldenhoven.de)

- Vaitoudden Winter test center, Sweden (ww.bosch-mobility-solutions.com)

- Millbrook Proving Ground, United Kingdom (www.millbrook.co.uk)

- Zala ZONE Jármüipari Tesztpálya, Hungary (www.zalazone.hu)

- Mcity, United States (www.mcity.umich.edu)

- Japan Automobile Research Institute, Japan (www.jari.or.jp)

- IDIADA, Spain (www.applusidiada.com)

Most of the test tracks included in the list have a relatively long history. Mercedes operates a track next to Stuttgart and in northern Germany at the Bosch Boxberg in Vaitoudden. Horiba-Mira - who is responsible for the design of the Zalaegerszeg facility - has a track in Great Britain, the Millbrook with one of the largest profit margins.

Looking at the full scale, we can see that the English government is making outstanding efforts to be the first in the competition of autonomous car development in Europe, but the largest classic automotive test tracks are typically owned by German companies. It is important to mention that the classic test tracks are relatively difficult to expand, so for the Zalaegerszeg test track the Catalan Idiada proving ground can be a competitor because it is also a new type and independent test track intended to be built for self-driving cars. Outside Europe, the University of Michigan's test track is noteworthy, a track that simulates urban conditions and as such, is currently the only professional track developed specifically for this purpose. The university-industrial investment currently operates on an area of 13-14 hectares.

If we compare it with the Hungarian investment, it becomes clear that the US MCity is testing on the previously mentioned 13-14 hectares, while the total area of the Hungarian facility will be 260 hectares, which shows a realistic picture of the size of the investment. The final budget of the investment will essentially peak at around HUF 45 billion. The M76 (formerly known as R76) smart roadwill be closely connected to the test track, the first phase of which will be completed by mid2020 for another HUF 38.8 billion. If we summarize everything during the two developments, we can get a budget of approximately HUF 110 billion. In connection with the M76 smart road, we have to highlight that we do not have final information yet as a HUF 170 billion final source was also previously mentioned which may mean a further increase at the value of the total investment (of course, exact financial data regarding the investment will be accessible after the completion of the test track project, as a need to include resources for other non-testing infrastructure developments is highly mandatory.) In the view of the terms of return, as the data on the annual return of the Zalaegerszeg test track are not at our disposal yet, we must use test tracks that have been operating in Europe for a long time. If we calculate with the previously announced 110 billion budget and we take into account the result of the British Millbrook (average HUF 4.2 billion per year), which makes the most profit of all European test tracks, the real period of investment returns can still be between 23 and 106 years. (Global UK Database, 2020; Hamar, \& Pataki, 2017).

\section{THEORY AND HYPOTHESES}

If we talk about proving grounds, it would be really important to define their impact on the economy. As the implementation of a proving ground has usually a really high cost, it can be expedient if we compare the investment costs and the expected incomes and results. Another question is the possible return. As we can see in the previous section, many experts forecast the potential ROI between 23 and 106 years. If this prognosis becomes true, then we can speak about a long return which can last for an unexpected time. In connection with the first issue, we want to justify the theory that test tracks have a great impact on the national economies. In the field of the return, our theory is that there is a strategic way with which we can reduce the return to less than 20 years. Therefore, at the current analysis, we had the following research questions and hypotheses:

Q1: What economic added value can the development of a test track mean?

H1: The implementation of a test track has a great impact on the entire national economy.

Q2: What are the strategic steps by which the test track can reduce its return of investment (ROI) to less than 20 years? 
H2: With appropriate strategic steps, the potential return of investment (ROI) can be reduced to less than 20 years.

\section{RESEARCH METHOD}

The research aims to identify the possible impacts of the implemented proving ground in Zalaegerszeg and those strategic actions with which the investment can be successful after its completion. As a research method, we chose systematic literature review to explore the most global processes of automotive R\&D and through the review results justify $\mathrm{H} 1$ hypothesis. Afterwards we made a SWOT analysis, an NPV calculation related to the Zalaegerszeg test track to get to know the current strategy and return. Finally, with the help of structured interviews (with three experts), we defined the possible future and the need for strategic steps to justify H2. The current paper is only the opening phase of a long-term research, by which we tried to analyze the existing literature and define the potential steps and aims of a future strategy.

\section{RESULTS}

In the framework of the literature review we tried to find objective sources and secondary data for international automotive processes, including domestic and international test tracks. During the literature analysis we used the search engine of ssrn.com, Google Scholar, Scopus and doktori.hu, where we worked with the following terms at first: "test track", "automotive test track", "automotive testing". Because the search gave a relatively small number of relevant sources, we changed and used the term of "proving ground" hereafter. Under this search term, relevant literature could already be found for the general descriptions of test tracks, but they had mostly engineering nature and did not reflect the economic context. Finally, analyzing economic websites, online journals and test tracks' webpages was the most expedient approach to justify our research goals. As a partial result of the literature review, we got the result that there is a severe shortage of elated publications on the topic and therefore further research in this field is really important, (Gubán, \& Kása, 2013; Kása, \& Gubán, 2015).

\section{Impact of the proving ground on the national economy}

If we examine the expected return on investment on its own, we get a clear result based on the previous chapter. (We mentioned the real return can be between 23 and 106 years.) On the other hand, it is important to note that an $R \& D$ investment should not be judged only on the basis of the rents paid by the companies testing there. Accordingly, we are trying to find an answer to the economic added value of this type of investment, which we will demonstrate with the help of foreign examples. To identify the processes, we examined the structure of the German automotive industry because - like the Hungarian economy - it is an export-oriented economy, and because of this, it is very exposed to global business processes. In addition to similar characteristics, it is important to emphasize that Hungary's economic performance is highly dependent on the performance of the German automotive industry, which can also be seen in the breakdown of the data. German companies created 300,000 new jobs in Hungary, out of which more than half were in the automotive industry. Based on the breakdown of foreign direct investment in Hungary by country, Germany has the highest portfolio, representing a share of almost $30 \%$. In 2018, the automotive industry meant $30 \%$ of the manufacturing industry, it was responsible for $3-4 \%$ of the Hungarian GDP on annual basis. Furthermore, an important factor is that most of the Hungary-based companies operating in the industry were able to record their revenues from exports to Germany, (Vápár, 2013). The performance of the automotive industry has a critical impact on the country's economic strength in Germany. It maintains 820,000 jobs domestically, total revenue was $€ 423$ billion in 2017, and contributes about 5\% to Germany's gross domestic product. If we want to place the automotive industry in the German economy, we can say that it involves a very significant contribution to GDP between 5 and $10 \%$ annually. To identify the share of test tracks within this result, the next step was to analyze the $R \& D$ indicators. At this point of the paper, we have partially uncovered our research area whether the investment has a measurable impact on the national economy. A further question is the size of this impact. We have to identify that the investment's impact is overall enough to define the region's long-term development aims (another dimension is its price value, we have to analyze the possible influence in comparison with the 
construction price.). Statista's relevant statements are the ones that may facilitate a far more precise determination of the proportions.

The research identified the share of companies with high innovation and R\&D in the industry at around $63 \%$ on average. To determine the size of innovative developments in German automotive industry, an additional benchmark may be the share of revenue from newly developed cars in total supply (Figure 1).

On Figure 2, it can be seen that the share of completely newly developed products fluctuates around $10 \%$, while subsequent innovations like the adaptation of a solution already developed by a competitor, represent an additional $40 \%$.

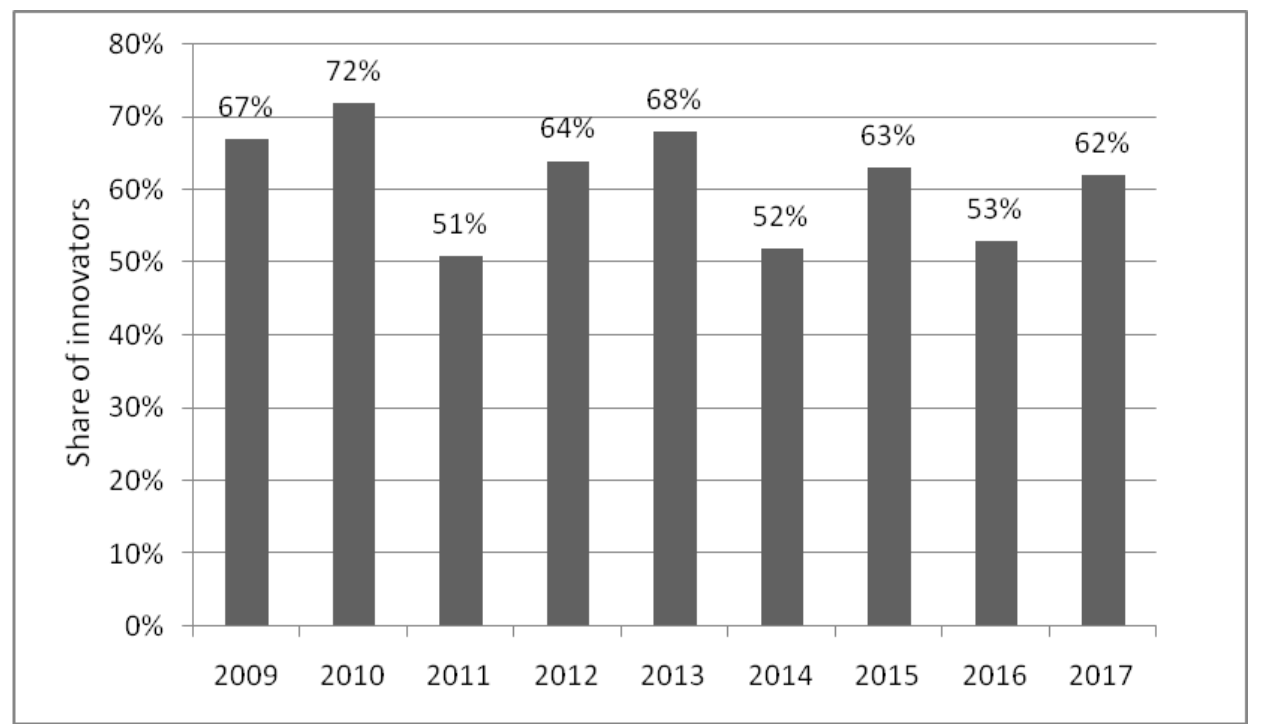

Figure 1: Share of innovators in Germany from 2017 to 2018 in automotive industry (Statista, 2020)

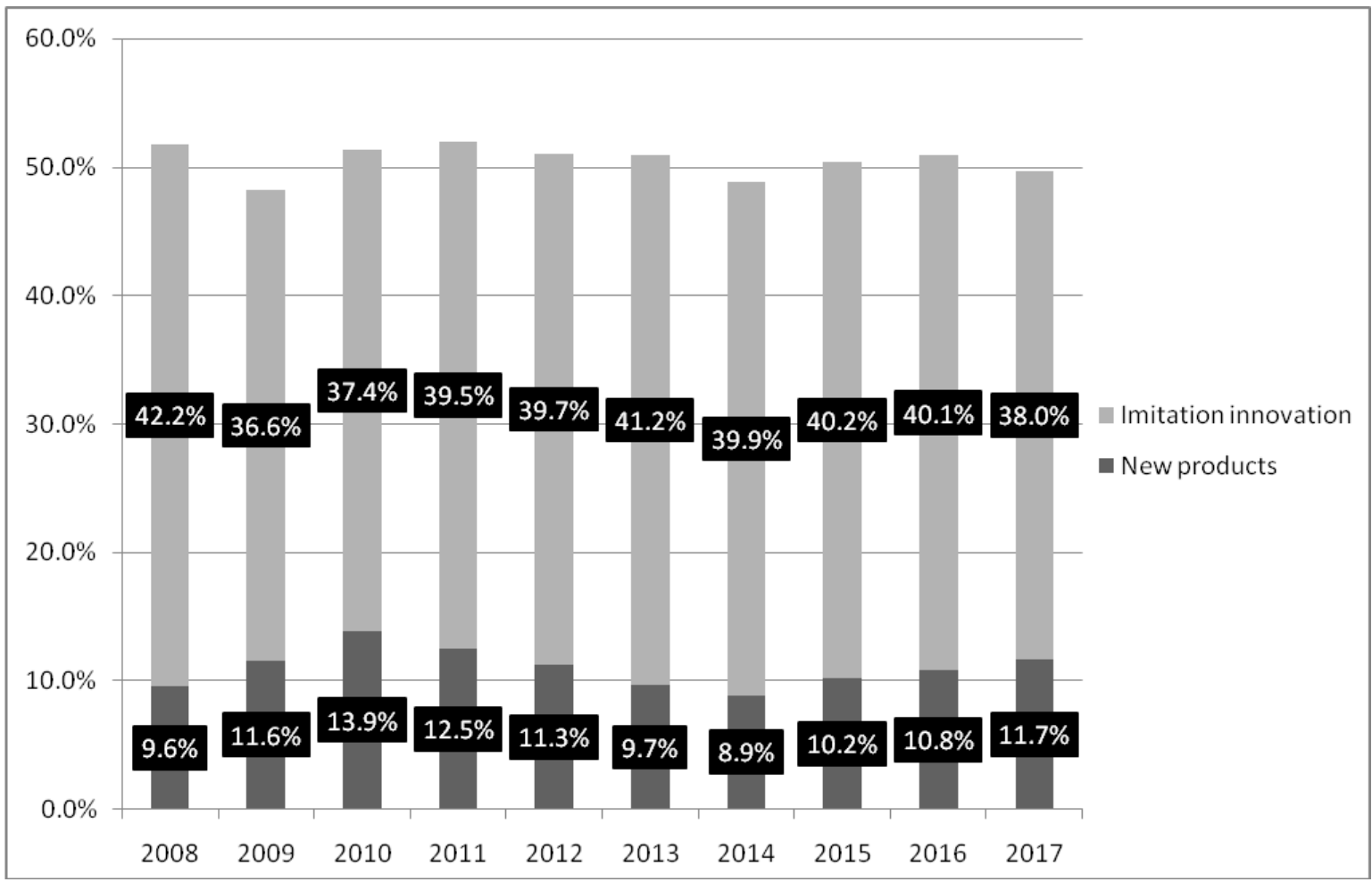

Figure 2: Share of new products from 2017 to 2018 in German automotive industry

(Statista, 2020) 
In view of the received results one factor must be clarified. Where will be the R\&D results utilized? The common market practice has been so far that for-profit companies build a test track for themselves, so in their case the answer was essentially evident. At the Zalaegerszeg test track an important question will be from the point of view of profitability, whether it will be able to draw a profit in any ways from R\&D or it will simply lease the infrastructure. It may be hopeful that in parallel with the construction of the test track, a research center called Smartfield has been set up in the field, so if R\&D activities are carried out locally (on behalf of the state), this could greatly facilitate the potential return.

At the possible return of the test tracks, we have been mostly examining ROI mainly on the basis of rents and possible R\&D activities, but another aspect is the inflow of capital and the development of the supplier network within it. In connection with the supplier network, the Papenburg test track could be a good practice. Thanks to the proving ground, a supplier network of more than 20 companies has been established in the area and significant foreign capital inflows (more than $€$ 130 million) have taken place since its opening in 1998.This did not take place exclusively through the supplier network, but essentially Wilhelm Karmann GmbH and MB-technology $\mathrm{GmbH}$ acquired the entire infrastructure (they still own the test track), (Focus, 2011).

It is also important to see the differences in the case of the Papenburg test track compared to the Zalaegerszeg test track. The main difference may be that in the case of Zala Zone, the investment is much larger, so hopefully the number of suppliers will also be wider and the capital inflow will be in balance with the size of the investment. Nonetheless, we can certainly draw the conclusion that the partial sale of ownership can also help the return in the case of Zala Zone. Of course, this is not a primary goal, but it can be definitely useful if an escape route is needed.

In summary, throughout the literature review, we identified that automotive $R \& D$ has a prominent place within the industry and the performance of the automotive innovation sector not only significantly affects the automotive industry itself, but typically the entire national economy (based on secondary data, this was explained to Germany and indirectly to Hungary). By the obtained results $\mathrm{H} 1$ hypothesis was confirmed and become thesis as we identified that the implementation of a test track has a great impact on the entire national economy, (Majó-Petri, \& Huszár, 2020).

\section{NPV calculation}

A relatively small number of resources are available in relation to the previous vision of the investment. Based on these, the essence of the project was to create a test environment that provides multi-level testing capability from prototype tests to serial product development, (Zalazone, 2019). As we did not find any return objectives, we tried to analyze the investment through NPV calculations. The NPV calculation gives only a bottleneck picture about the current strategy, and a possible answer to that question besides the current operation, is the investment worth it? (Illés, 2012).

At the NPV Calculation, the basic formula is the following:

$$
N P V=\sum_{i=1}^{n} \frac{C_{t}}{(1+r)^{t}}-C_{0}
$$

where:

$-n$ is the time of the cash flow

- $r$ is the discount rate, i.e. the return that could be earned per unit of time on an investment with similar risk

- $C_{t}$ is the net cash flow i.e. cash inflow (at t time point)

- $C_{0}$ is commonly placed to the left of the sum to emphasize its role as (minus) the investment.

Our NPV calculation was based on the cost value of HUF 45 billion and the average profit of the European test tracks, which was counted HUF 1.16 billion on an annual basis. The expected return was set at $6 \%$, based on government securities as a safe investment opportunity.

In a 3-year cycle, the net present value was the following:

$$
\begin{aligned}
& N P V=-45+1.16 \cdot(1.06)-1+1.16 \cdot(1.06)-2+ \\
& 1.16 \cdot(1.06)-3=-41.901
\end{aligned}
$$


Table 1: Calculation of the net present value of the test track for a 20-year cycle (Source: Author)

\begin{tabular}{|c|c|}
\hline Required return & Net present value \\
\hline 6\% & $\mathbf{- 3 2}$ \\
\hline Period (year) & Cash flow \\
\hline 0 & -45 \\
\hline 1 & 1,16 \\
\hline 2 & 1,16 \\
\hline 3 & 1,16 \\
\hline 4 & 1,16 \\
\hline 5 & 1,16 \\
\hline 6 & 1,16 \\
\hline 7 & 1,16 \\
\hline 8 & 1,16 \\
\hline 9 & 1,16 \\
\hline 10 & 1,16 \\
\hline 11 & 1,16 \\
\hline 12 & 1,16 \\
\hline 13 & 1,16 \\
\hline 14 & 1,16 \\
\hline 15 & 1,16 \\
\hline 16 & 1,16 \\
\hline 17 & 1,16 \\
\hline 18 & 1,16 \\
\hline 19 & 1,16 \\
\hline 20 & 1,16 \\
\hline & \\
\hline
\end{tabular}

As it is clearly visible for a 20 -year cycle, we get the result that this form of investment is not worth it. However, it is important to note that test track should not be explicitly examined in terms of rents, as the development of a proper supplier network in the region can greatly shorten the needed returns. From this aspect, the current net present value calculation essentially reflects the current strategy as part of the self-knowledge tools which helps us define the strategic goals, (Szücsné, 2012).

\section{SWOT analysis}

With a SWOT analysis we mapped the market, industry, business, the market viability and which tasks are the most important from a strategic point of view in connection with the Zalaegerszeg proving ground (Table 2). Throughout the analysis section, we wanted to identify those processes which are relevant from a future strategy side. We used the previously acquired literature review results, expanded them with other pieces of literature.

In the field of strengths, one of the most fundamental is that local track equipment outperforms all European test tracks. Related to this, it is important to note, which we have already explained - testing in simulated urban conditions is only possible at the University of Michigan outside Zalaegerszeg proving ground. Another important strength is that management is made up of professionals who are recognized as both engineers and managers. The professional approach they represent, as well as the network of connections they possess, can be one of the strengths of the track.

Table 2: SWOT analysis of the Zalaegerszeg test track (Source: Author)

\begin{tabular}{|c|c|}
\hline Strengths & Weaknesses \\
\hline $\begin{array}{ll}- & \text { Extensive } \\
& \text { technological } \\
& \text { infrastructure } \\
- & \text { Possibility to test } \\
& \text { urban conditions } \\
- & \text { Professional } \\
& \text { (engineering) } \\
\text { management }\end{array}$ & $\begin{array}{l}- \text { High priced } \\
\text { investment } \\
-\quad \text { Difficult handling of } \\
\text { company secrets } \\
-\quad \text { Disadvantages arising } \\
\text { from state operation }\end{array}$ \\
\hline Opportunities & Threats \\
\hline $\begin{array}{ll}- & \text { Strong regional } \\
\text { automotive traditions } \\
- & \text { Existence of local } \\
& \text { higher education } \\
- & \text { Strong political } \\
& \text { support } \\
- & \text { Few competitors }\end{array}$ & $\begin{array}{ll}- & \text { Possibility of long } \\
& \text { return } \\
- & \text { Lack of human } \\
& \text { resources } \\
- & \text { Recession or } \\
& \text { economic slowdown } \\
- & \text { Low investment } \\
& \text { sentiment }\end{array}$ \\
\hline
\end{tabular}

One of the most obvious weaknesses is the high volume of investment costs. This will be decided by the future if the technical solutions were developed in proportion with their costs. By not building the track for a specific company for its own purposes, according to the concept more (even competing) companies will test in one place. In this case, a delicate issue is that how the test results can be separated and how confidentiality can be resolved for competing firms. State operation is a weakness, mainly in that field the state is not always committed in the field of profitable operation, and if it is, it does not always work on the same level as a for-profit company usually does.

When it comes to opportunities, a good start could be that many automotive investments in the region are working well. It is enough to consider Audi in Györ or the supplier network in the region. This network can provide a foundation to which a wellfunctioning test track can connect. The fact that the city has both economic and engineering higher education institutions can be a further help for networking. In addition, it should be mentioned 
that there is a high level of political support for the concept, which can even lead to a foreign recognition and some orders. One of the most undisputed opportunity is the early market entry. As we mentioned formerly, there is currently no such well-equipped track in Europe, so if the needs have been properly assessed, we can confidently say that Zalaegerszeg test track has introduced its concept ahead of potential competition.

As we explained at the beginning of our paper, the investment has a really high price, so if market demand has been poorly assessed in advance (and the volume and equipment is actually unnecessary), we are facing a very difficult or never-to-return investment. An additional threat may be the growing difficulty of labor shortages in the region. In Zalaegerszeg, the unemployment rate is currently $2.3 \%$, which now includes only those unemployed who cannot be physically included in the labor market. An even bigger problem is the lack of a skilled workforce. Preliminary calculations, as outlined earlier, could be greatly overwhelmed by a possible recession or economic slowdown. Of course, this type of ripple can also affect the test track in several ways, as we explained earlier, (Nyugat-Dunántúli Regionális Fejlesztési Ügynökség Közhasznú Nonprofit Kft., 2013; Pickton, \& Wright, 1998).

\section{Possible future}

If we want to make the right strategic steps, we have to get to know the entire automotive sector's future first. In the framework of getting to know the possible future, we made structured interviews with three economic experts, namely with Miklós Kókai - microfinance expert of the Zala County Foundation of Enterprise Promotion, with Attila Matics - economic consultant of the City of Zalaegerszeg and with Viktor Tóth, - venture capital investor and managing owner of West Practice Hungary Consulting Ltd.

As a summary of the interviews, we got an unfortunate picture, as even more positive forecasts predict a strong economic slowdown, while more negative overtones indicate a definite recession. Based on the structured interviews, we can identify the following main factors behind the slowdown:

- Previous emission scandals (especially for the VW group),

- Pollutant emission regulations,
- Danger of an untidy Brexit,

- Trade war

- Declining Chinese and American sales,

- Increasing domestic production in China (due to the technological development).

Perhaps only the last of these factors needs some explanation. Forecasts from years ago have shown that, in parallel with the development of Chinese car production, Chinese manufacturers are able to supply their own domestic markets in increasing volumes, thus reducing the export capacity of the German car industry proportionately. What contributes to this is, of course, nothing other than Brexit, as the UK is another major export destination for the German car industry, so the result as a combination of all factors is nothing more than a sharp slowdown in the German economy (based on the interview with Viktor Tóth). Global economy today is characterized by slow developmental growth and especially by the insufficient growth of the global trade, (Bakator et al., 2019).

The important question is that how this slowdown will affect Hungary: "The external slowdown has already begun to subtly feel its effect. As a result of the German manufacturing industry contraction, Hungarian industrial production also declined. This year, industry typically grew by 4-8 percent per month (annual comparison). Based on recent numbers of August, Hungarian industry grew by only 2.7 percent (based on seasonally and calendar-adjusted data). The car production contributed significantly to the slowdown as a heavy stakeholder. Although one piece of data is not satisfactory, the MNB - Hungarian Central Bank - forecasts that the slowdown in the Eurozone may spill over to us in the second half of this year." (Fülöp, 2018; Harsányi, 2019).

In addition to the forecast described above, an important positive consequence should also be highlighted. Namely, that the Hungarian manufacturing industry is relatively resilient to the possible slowdown, as the Hungarian factories are developed, cost-effective and mostly producing cheaper models for which the demand has not fallen so much. All in all, the question is not whether the slowdown will ring in here, but rather when. Fortunately, thanks to our industrial structure, the economic downturn will only come with a delay. If we analyze this process in connection with Zala Zone, we cannot set a 
definite direction for the future, as this "event horizon" can have multiple outputs. On the one hand, we consider a real danger that despite the fact that the slowdown does not affect the Hungarian car industry, a crucial point will be to find out what amount of extra capital automotive companies can spend on R\&D. Taking the most optimistic scenario, another possible outcome is that Zala Zone will not be affected by the slowdown, as they are testing self-driving technologies for future directions, so manufacturers will have an increased interest in developing them. (Based on the interview with Miklós Kókai) So, from this view, the R\&D can be an out-breaking-point for the automotive companies from the slowdown spiral, (Pherson, 2018). Our society, and with our economy and industries, is undergoing fundamental shifts towards an intensely digitized lifestyle, (Schaeffer, 2017). Technology is the most dynamic development factor. The world has stepped into Information era whose essence is in communication, leaving the Industrial one behind, (Djordevic et al., 2016).

\section{Strategic steps}

The other half of the interviews was in connection with the possible strategic actions - which can even reflect the previously mentioned future processes. The most common part in the interviews was the need of a supplier network. This demand was not just identified in the qualitative parts of the research, but also at the quantitative - NPV calculations. On the basis of these results, we can say that we only can reach an acceptable return if the supplier network is out-built in the area. During the second half of the interviews, we were looking for the actual steps for it.

If we want to achieve a supplier network that also plays a significant economic role on a regional level, one of the most important factors is networking. Educational institutions, local governments, economic foundations, chambers, as well as financial service providers and companies with an industrial profile can be active players in terms of investment. Another part of networking is the facilitation of $b 2 b$ processes, i.e. the facilitation of economic cooperation between customers and potential suppliers. Both enterprise development foundations and chambers, but also universities and local industrial enterprises can be in connection with domestic or even foreign enterprises from which the companies testing here can find new suppliers. In addition to networking, it is also important to strengthen the core business activity, which means to maximize the leasing of test sites and rents (Based on the interview with Attila Matics). As this activity is largely related to the previously described networking, therefore the same tasks are given in this case. Besides networking, it is really important at a state investment to ensure the right economic environment to the companies. In addition to the appropriate mentoring activities, we can help SMEs to become suppliers mainly through financing. Zala County Foundation for Enterprise Promotion also provides several types of microloan currently, which should be worthwhile to supplement with a special type of construction designed to encourage becoming a supplier. Another important part of inducing suppliers is the right infrastructure. For this purpose, it may even be worthwhile to set up joint warehouses / hubs, which the supplier and the buyer can rent and operate according to a mutual agreement. In summary, the strategy-making dimensions can be the following for the investment:

- Promoting the networking of local stakeholders

- Active search for economic partners and development of the platform necessary for it.

- Strong core business activity, maximum utilization of rents.

- Existence of financing and business start-up instruments.

- Providing adequate infrastructure.

Based on the obtained results, the $\mathrm{H} 2$ hypothesis was confirmed and it became a thesis as we identified needed strategic steps to reduce the potential return to less than 20 years.

\section{CONCLUSIONS AND PROPOSALS}

Throughout the research, we were investigating the possible economic added value that the Zala Zone test track could produce. Through the literature review, it was clearly visible that the most part of the existing literature is engineering-based so the further analysis in this filed is important. As a further part of the literature review, we wanted to identify the possible impacts of the future implemented test track. In this field - through the foreign best practices - we got the result that the test tracks - as well as the automotive R\&D, have a great impact not just on the sectoral outputs but also on the whole national performance. (On the ground of this result $\mathrm{H} 1$ hypothesis was 
confirmed). In the second section of our paper, we analyzed the current situation within the framework of a SWOT analysis and an NPV calculation. Here, we identified the most important strengths, weaknesses, opportunities and threats, while with the NPV calculation the obtained results indicate that in order to make the investment a profitable decision, the encouragement of a supplier network is an absolute necessity. With the help of the structured interviews, we expanded the received results with possible future processes and strategic steps which help shorten the return. We identified that, with the help of needed strategic steps (implemented supplier network, basic financial instruments, networking of local stakeholders), there is an existing approach which can reduce the return to less than 20 years. With the obtained result $\mathrm{H} 2$ hypothesis was confirmed.

As a final result of our research, we could highlight the main parts and dimensions of a future strategy, so our next task is to continue the already commenced work and in the next phase(s) we have to describe strategic steps and actions in a more specific way.

\section{REFERENCES}

Bakator, M., Djordjevic, D., \& Cockalo, D. (2019). Developing a model for improving business and competitiveness of domestic enterprises. Journal of Engineering Management and Competitiveness, 9(2). 87-96.

Djordjevic, D., Cockalo, D., \& Bogetic, S. (2016). The analysis of marketing concept implementation in domestic enterprises. Journal of Engineering Management and Competitiveness, 6(2). 120-128.

Focus. (2011). MBtech zu 65 Prozent an Akka Technologies verkauft. Retrieved from https://www.focus.de/finanzen/finanz-news/daimlermbtech-zu-65-prozent-an-akka-technologiesverkauft_aid_692003.html

Fülöp, Z. (2018). Digitalizáció és foglalkoztatás: összefoglaló az MKT Munkaügyi Szakosztálya és az Innovációs és Technológiai Minisztérium 2018. május 24-i közösrendezvényéröl. Munkaügyi Szemle Online, 7,1-3.

Global UK Database (2020). Millbrook Proving Ground Limited. Retrieved fromhttps://uk.globaldatabase.com/company/millbro ok-proving-ground-limited

Gubán, Á., \& Kása, R. (2013). A literature-based review of business process amelioration methods and techniques regarding service orientation. Journal of Advanced Management Science, 1(2), 230-235.
Haas, P., \& Cselle, F. (2017). Autóipari próba pálya Zalaegerszegen. Innotéka. Közlekedés fejlesztési különszám. Retrieved fromhttps://www.innoteka.hu/cikk/autoipari_probap alya_zalaegerszegen.1579.html

Hamar, Z., \& Pataki, M. (2017). Zalaegerszegi tesztpálya müszaki bemutatása, fejlesztés kivitelezésének koncepcionális kérdései. IFFK 2017 Konferencia. Budapest. 1-5.

Harsányi, P. (2019). Érik az európai recesszió? Retrieved fromhttps://novekedes.hu/elemzesek/erikaz-europai-recesszio

Illés, M. (2012). A nettó jelenérték gazdasági tartalma és rangsorképzésrevaló alkalmassága. Vezetéstudomány - Budapest Management Review, 43(1), 13-23.

Hungarian Government (2011). 1222/2011. (VI. 29.) Korm. határozatgyorsforgalmi- és a föúthálózat hosszútávú fejlesztési programjáról és nagytávú tervéröl. Retrieved fromhttps://net.jogtar.hu/getpdf?docid=A11H1222.K OR\&targetdate $=\&$ printTitle $=1222 / 2011$.+(VI.+29.) + Korm.+hat\%C3\%A1rozat\&getdoc $=1$

Kása, R., \& Gubán, Á. (2015). Business Process Amelioration Methods, Techniques and their Service Orientation: A Review of Literature. Research in the Decision Sciences for Global Business, Upper Saddle River: Pearson, 219-238.

Majó-Petri, Z., \& Huszár, S. (2020). Autonóm jármüvek, önvezető autók: mitgondol a közönség? Közlekedés tudományi Szemle, 70(1), 66-75.

Nyugat Dunántúli Regionális Fejlesztési Ügynökség Közhasznú Nonprofit Kft. (2013). Zala Megye Terület fejlesztési Koncepció. Budapest.

Pherson, R. H. (2018). Leveraging the Future with Foresight Analysis. The International Journal of Intelligence, Security, and Public Affairs, 20(2), 102-131.

Schaeffer, E. (2017). Industry X.O. Redline-Verlag and Kogan Page.

Statista (2020). Automobile industry in Germany Statistics \& Facts. Retrieved fromhttps://www.statista.com/topics/3202/automobil e-industry-in-germany/

Szücsné, M. K. (2012). A beruházás gazdaságossági számítások gyakorlatban alkalmazott módszerei.Vezetéstudomány - Budapest Management Review, 43(1), 97-107.

Pickton, D.W., \& Wright, S. (1998). What's SWOT in strategic analysis? Strategic Change, 7(2),101-109.

Vápár, J. (2013). A német működő tőke-befektetések Magyarországon. Térés Társadalom, 27(1), 129144.

ZalaZone (2019). Pályavízió - A project lényege. Retrieved from https://zalazone.hu/palyavizio/aprojekt-lenyege/ 


\section{STRATEŠKA ANALIZA ZALAEGERSZEG TEST POLIGONA}

Ulaganje Zalaegerszeg test poligona završeno je vladinom uredbom - br. 1292/2016. (VI. 13.) - koji je bio konačni rezultat dvogodišnjeg timskog rada na celokupnoj pripremi, upravljanju resursima i drugim proračunima i analizi povrata investicije. Izgradnja je počela 2017. godine, nakon čega je prva faza završena u 2018. godini (u skladu sa planiranim rokovima), dok je konačni datum razvoja predviđen za kraj 2020 godine. U ovom radu analiziraće se alternative primene test poligona u različitim oblastima privrede kao i povrat investicija sa strateške strane . Najvažniji cilj ove analize bio je istraživanje potencijalnih rezultata investicije , što omoguća va bolji uvid u ekonomske, društvene i druge efekte test poligona

Ključne reči: Automobilska indiustrija; Poligon; Strategija. 